IOSR Journal of Pharmacy

ISSN: 2250-3013, www.iosrphr.org

||| Volume 2 Issue 5 ||| Sep-Oct. 2012 ||| PP.31-33

\title{
Effect of Ethanolic Extract of Gnetum africanum on Lipids and Lipoprotein Profiles in Rats
}

\author{
Francis Vincent Udoh $^{1}$, Nelson Chukwudi ${ }^{2}$ and Albert P. Ekanem ${ }^{3}$ \\ ${ }^{1}$ Department of Pharmacology, College of Medical Sciences, University of Calabar Calabar, Nigeria \\ ${ }^{2}$ Department of Public Health, College of Medicine, University of Calabar Calabar, Nigeria. \\ ${ }^{3}$ Institute of Oceanography, University of Calabar, Nigeria.
}

\begin{abstract}
Gnetum africanum is native to West and Central Africa. The Phenotypic diversity within the Gnetacea is significant in the Niger Delta region of Nigeria where the leaf is consumed as vegetable. The ethanolic extract of the leaf was Soxhlet extracted. Three graded doses were estimated by acute toxicity tests. 20 female rats weighing between 120-150 grams were divided into 4 groups. Group 1-3 received (10, 200, and $700 \mathrm{mg} / \mathrm{kg} / \mathrm{d}$ ) of extract, group 4 received Normal Saline as control, respectively, for 7 days. Rats of all groups were sacrificed on the $8^{\text {th }}$ day after treatment, and blood collected, allowed to clot for centrifugal separation into cells and serum. Separated Sera were used for Lipid profiles estimation. Results showed that, ingestion of G. africanum extract caused increase in the serum levels of High Density, Low Density Lipoproteins, Cholesterol and triglycerides, as well as decreased bilirubin level. Increase in serum levels of total cholesterol, triglycerides and LDL- cholesterol were positively correlated with incidence of coronary heart disease (artherosclerosis). Increase in the serum level of high density lipoprotein could impact a corrective effect on the precipitated artherosclerosis. On the other hand, reduction in serum bilirubin suggests non-hepatoxic effect of the plant.
\end{abstract}

Keywords—Albino rat, Gnetum africanum, Lipids and Lipoproteins profiles.

\section{INTRODUCTION}

The plant, Gnetum africanum (family: Gnetacea) locally called afang, is a leafy vegetable commonly eaten by most people of the Niger Delta region of Nigeria. It is commonly grown in tropical areas of Niger Delta, Nigeria. It is a wild climbing plant with dark-green leaves tasting sweet. It is cultivated as vegetable in the farm yards by some people in rural areas of the Niger Delta region of Nigeria. The leaf of Gnetum africanum is considered superior to all other vegetables by the Niger Delta people.

It is likely that the use of the leaves of Gnetum africanum as vegetable may lead to some interference in biochemical function of the liver ([1]). The objective of the study is to investigate the effects of ethanolic extract of G. Africana on lipids and lipoprotein of albino rats.

\section{MATERIALS AND METHODS}

\subsection{Collection and Extraction of Plant}

The leaves of G. africanum were fetched from the tropical swamp forest of Calabar, Nigeria, in the months of March and April, 2010. The whole plant was authenticated by Dr. Ani Nkang of the Department of Botany, University of Calabar, Nigeria, as G. africanum. A voucher specimen was deposited in Herbarium unit of the Department of Pharmacology, University of Calabar, Nigeria.

The leaves of the plant were washed in tap water to remove dirt and dried overnight at room temperature of $28 \pm 1^{\circ} \mathrm{C}$. The dry leaves were cut into slices and blended into powder using an electrical blender (Behrmanning Troy, N. Y).

The Powder sample $(100 \mathrm{~g})$ of the leaf of G. africanum was wrapped in a Watt- man filter paper and placed in 500ml Soxhlet extractor and extracted with ethanolic as solvent following the method described by ([2]). The plant sample placed in Soxhlet extractor was first extracted in absolute petroleum ether for $8 \mathrm{~h}$. The petroleum ether extract was removed and the residues left in the Soxhlet chamber were re-extracted in absolute ethanol for $72 \mathrm{~h}$. The extract in the ethanol was evaporated using a rotary evaporator in vacuo, at a reduced temperature of $40^{\circ} \mathrm{C}$. About $40 \mathrm{~g}$ of the ethanolic solid extract was dissolved in $100 \mathrm{ml}$ of distilled water, then mixed in equal volume of chloroform and allowed to stand overnight for proper partitioning into two phases. The chloroform phase was separated from water using separating funnel. The water fraction was then evaporated into solid form. The solid extract was tested to contain alkaloids with negligible amount of tannins. 


\subsection{Animal Treatment}

About 20 adult rats of both sexes weighing between 120-150 g were obtained from the Animal House Unit of the Department of Pharmacology, University of Calabar, Nigeria. The rats were allowed to acclimatize in the laboratory for a period of 7 days. They were housed in standard cages and allowed free access to standard pelleted diet and water ad Libitum.

The rats were divided into four groups of 5 per group. Groups 1,2 and 3 received alkaloid extract of $G$. africanum, 10, 200 and $700 \mathrm{mg} / \mathrm{kg} / \mathrm{d}$, respectively, while group 4 received normal Saline as control, for 7 days.

\subsection{Preparation of Serum}

Blood samples were collected from the test animals, through cardiac puncture, into clean centrifuge tubes. They were allowed to clot for 30 minutes and the Seri were separated by centrifugation. The Sera were collected into reagent bottles and used in the experiment.

\subsection{Estimation of Lipoproteins}

Serum cholesterol level was estimated by the activity of cholesterol esterase on the cholesterol ester to produce cholesterol and free fatty acids. Serum levels of HDL- and LDL- cholesterols and triacyglycerol were estimated calorimetrically by measuring the color change developed in the respective test samples.

Determination of serum levels of bilirubin was based on the colorimetric method of Jendrassik and Gof as modified by ([3]; [4]). Direct bilirubin was estimated by configurated sulphanilic acid in alkaline medium to form a blue color complex. Total bilirubin, the albumin bound bilirubin was determined in the presence of caffeine, which released albumin from albumin-bound-bilirubin complex by reacting with diazotized sulphanilic acid, later measured calorimetrically.

\subsection{Statistical Analysis}

Data obtained from this work were analyzed statistically using the one way analysis of variance (ANOVA) and Turkey-Kramer multiple comparison test. Differences between means were considered significant at $1 \%$ and $5 \%$ level of significance, $\mathrm{P}<0.01$ and 0.05 , ([5]; [6]).

\section{RESULTS}

Oral administration of ethanolic extract of G. africanum at 10,200 and $700 \mathrm{mg} / \mathrm{kg} / \mathrm{d}$ to female rats for 7 days raised the serum concentration of high density Lipoprotein cholesterol. The increased serum HDLcholesterol was significant $(\mathrm{P}<0.05)$ for the treatment groups.

It was further observed that treatment with the alkaloids extract of $G$. africanum induced increase in serum LDL-cholesterol. This was significant in the group treated with $700 \mathrm{mg} / \mathrm{kg} / \mathrm{d}(\mathrm{P}<0.05)$ compared to the control (Table1). Whereas, treatment with 200 and $700 \mathrm{mg} / \mathrm{kg} / \mathrm{d}$, did not induce significant changes in serum triacyglycerol. On the contrary, $10 \mathrm{mg} / \mathrm{kg} / \mathrm{d}$ induced a significant $(\mathrm{P}<0.05)$ increase in the triacyglycerol serum level (Table 1).

TABLE 1: Effect of Ethanolic Extract of Gnetum africanum Repeated Administration for $\quad 7$ Days on Serum Lipids and Lipoprotein- Cholesterol Profiles in Albino Rats

\begin{tabular}{|c|c|c|c|c|}
\hline \multirow{2}{*}{$\begin{array}{l}\text { Treatment } \\
(\mathrm{mg} / \mathrm{kg} / \mathrm{d})\end{array}$} & \multicolumn{4}{|c|}{ Lipid Profiles (mmol/l) } \\
\hline & HDL & LDL & CHOL & TG \\
\hline $\begin{array}{l}\text { Control }(2 \mathrm{ml} \text { of } \\
0.85 \% \mathrm{NaCl})\end{array}$ & $2.0 \pm 0.1$ & $0.02 \pm 0$ & $4.75 \pm 0$ & $41.8 \pm 1$ \\
\hline EE (10) & $3.7 \pm 0.05$ & $0.1 \pm 0$ & $18.1 \pm 0.7^{*}$ & $83 \pm 1$ \\
\hline EE (200) & $3.1 \pm 0.1$ & $0.1 \pm 0$ & $2.2 \pm 1 *$ & $41.2 \pm 0.05$ \\
\hline $\mathrm{EE}(700)$ & $67.8 \pm 0.1$ & $0.37 \pm 0.1^{*}$ & $25 \pm 1 * *$ & $43.9 \pm 0.05$ \\
\hline
\end{tabular}

Key

$* \mathbf{P}<0.01, * * \mathbf{P}<0.05$ by student $\mathrm{t}$-test, each group compared with the control.

HDL = High Density Lipoprotein

LDL $=$ Low Density Lipoprotein

$\mathrm{CHO}=$ Cholesterol

TG $=$ Triacyglycerol

$\mathrm{EE}=$ Ethanolic Extract

$* \mathrm{P}$ or $* * \mathrm{P} \quad=$ significantly different from control

The results of another study of the activity of ethanolic extract of G. africanum administered at 10, 200 and $700 \mathrm{mg} / \mathrm{kg} / \mathrm{d}$ to rats for 7 days induced significantly $(\mathrm{P}<0.01$ ), dose dependent decrease in serum concentration of Direct bilirubin (Table 2). However, these doses of the extract did not alter the serum level of total bilirubin compared to the control, $\mathrm{P}>0.01$. 
TABLE 2: Activity of Ethanolic Extract of the Leaf of Gnetum africanum Oral Administration, Daily For 7 Days on the Serum Levels of Direct and Total Bilirubins in Rats

\begin{tabular}{|l|l|l|}
\hline \multirow{2}{*}{ Treatment Dose $(\mathrm{mg} / \mathrm{kg})$} & Serum Bilirubin $(\mathrm{mmol} / \mathrm{L})$ \\
\cline { 2 - 3 } & Direct & Total \\
\hline Control $(2 \mathrm{ml}$ of $0.85 \% \mathrm{NaCl})$ & $19.7 \pm 0.1$ & $8.8 \pm 0.01$ \\
\hline $\mathrm{EE}(10)$ & $3.5 \pm 0.1^{*}$ & $9.5 \pm 0.1$ \\
\hline $\mathrm{EE}(200)$ & $2.1 \pm 0.1^{*}$ & $9.5 \pm 0.1$ \\
\hline $\mathrm{EE}(700)$ & $1.0 \pm 0.05^{*}$ & $9.0 \pm 0.05$ \\
\hline
\end{tabular}

Key

$* \mathbf{P}<0.01, * * \mathbf{P}<0.05$, by student t-test compared with control.

$\mathrm{EE}=$ Ethanolic Extract

\section{DISCUSSION}

The ethanolic extract of the leaf of G. africanum administered to rats of both sexes caused increase in the serum levels of lipids and lipoprotein cholesterols. This increase was dose related. The increase in high density Lipoprotein-cholesterol level was not statistically significant ( $\mathrm{P}>0.01)$. However, total serum cholesterol, triglycerides and low density Lipoproteins cholesterol levels were raised significantly following treatments with the ethanolic extract of $G$. africanum. The serum level of total cholesterol, triglyceride and LDL-cholesterol are positively correlated with the incidence of coronary heart diseases, particularly atherosclerosis' ([1]; [7]).

Although the extract caused an increase in the serum level of HDL-cholesterol which could impact a corrective effect on the incidence of coronary heart disease ([8]), the observed significant increase in the total cholesterol, triglyceride and LDL-cholesterol seems to suggest atherogenic potential for $G$. africanum ethanolic extract. The mechanism by which this extract caused increase in Lipid profiles is not properly understood but it might be connected with the effects of the phytochemical constituents of the extract on the Lipid biosynthetic machinery within the cell.

Further observation of the effect of the ethanolic extract of $G$. africanum on the serum level of bilirubin revealed no negative impact. However, the result suggests that the ethanolic extract of the leaf of $G$. africanum has no effect on the hepatic functions in rat.

\section{ACKNOWLEGDMENT}

We acknowledge Mr. Nelson Saviour of DAJOSON Technologies, for the typing of this manuscript.

\section{REFERENCE}

[1]. Snider MD, McGarry J D and Hanson R W. 2006. Lipid Metabolism 1: Synthesis,storage and utilization of Fatty Acids and Triacylglycerols In: Thomas M. Delvin, editor. Textbook of Biochemistry with Clinical correlations (6th edition). Wiley-Liss Publication, USA. P. 661-693.

[2]. Udoh, Francis Vincent. 2007. The Effects of Gnetum africanum leaf extracts on some Biochemical indices and endocrine functions in albino rats. Postgraduate School, University of Calabar, Nigeria.

[3]. Akpanabiatu M I, Umoh I. B, Eyong E U, Edet E. E and Uboh F E. 2006a. Influence of Rauwolfia vomitoria root back extract on cardiac enzymes of normal Wistar, Albino Rats. Recent progress in medicinal plants. Biopharmoceuticals, 14, 273-278.

[4]. Akpanabiatu M I, Umoh I B, Uoh F E and Udosen E O. 2006b. Effect of Nauclea Latifolia leaf extracts on some rats serum enzymes of clinical significance. Recent progress in medicinal plant. Biopharmaceutical, 14, 297- 304.

[5]. Baker, H. G. Plant and Civilization. London: Macmillan, P 110; 1972.

[6]. Lyakhovich A and Gasche C. 2010 Systematic Review: Molecular Chemoprevention of Colorectal Maligncy by mesalazine. International Journal of Gastroenterology and Hepatology,; vol 31(2) 202- 208.

[7]. Agrawal A, Houghton LA, Morit S et al. 2009. Clinical Trail: The Effects of a Fermented Milk Product Containing Bifidobacterium Lactis DN -173-010 on Abdominal Distension and Gastrointestinal transit in irritable bowel syndrome with constipation. Alimental Pharmacol. Therapeutic 29: 104-114.

[8]. Feray C. 2010. Towards predicting the therapeutic response in patients with hepatitis C. International Journal of Gastroenterology and Hepatology; vol 31 (2) 339-343. 